\title{
Commentary on the WHO 2008 classification of neoplasms arising from histiocytic and other accessory cells
}

\author{
Megan S. Lim
}

Received: 15 May 2009 /Accepted: 20 May 2009 / Published online: 23 July 2009

(C) Springer-Verlag 2009

Histiocytes and dendritic cells belong to a group of immunoregulatory cells that are responsible for antigen processing and presentation to lymphocytes. Neoplasms of histiocytic and dendritic origin are very rare [1], making up less than $1 \%$ of tumours in lymph nodes. Thus, information regarding epidemiology, prognosis and treatment [2, 3] is scarce. Table 1 summatizes the neoplasms derived from histiocytes and other accessory cells according to the 2001 and 2008 WHO classification.

A new entity that has been added to the 2008 WHO classification of histiocytic dendritic cell neoplasms is disseminated juvenile xanthogranuloma (JXG). JXG is a benign proliferation of histiocytes similar to those that occur in the dermis. The disease that occurs in adults with bone and lung involvement is referred to as ErdheimChester disease. Although most JXG are benign, activation of macrophages can lead to cytopenias, liver damage and death. Neoplastic cells are composed of small and oval to spindled histiocytes with bland nuclear features without nuclear grooves. Dermal lesions tend to have foamy (xanthomatous) cytoplasm with Touton-type giant cells. Similar to macrophages, the tumour cells express CD14, CD68 and fascin. CD1a is negative and S100 is positive in less than $20 \%$ of the cases. Some are clonal but no cytogenetic or molecular changes have been identified. An association with neurofibromatosis type 1 has been made.

Although the neoplastic cells are thought to be derived from dendritic cells, they were previously classified as soft

M. S. Lim $(\bowtie)$

Department of Pathology,

University of Michigan Medical School,

M5242D, Med Sci I, 1301 Catherine Road,

Ann Arbor, MI 48109, USA

e-mail:meganlim@umich.edu tissue tumours. The recognition of their origin from dermal/interstitial dendritic cells and association with other hematologic malignancies such as juvenile myelomonocytic leukaemia and Langerhans cell disease warranted their classification within the category of histiocytic and dendritic cell neoplasms. It is unclear whether the solitary forms of JXG should be considered a benign counterpart of disseminated JXG. In addition, the range of cytologic atypia that is exhibited by these tumours is also unknown.

Table 1 A summary of the neoplasms derived from histiocytes and other accessory cells in the 2001 and 2008 WHO classification

\begin{tabular}{|c|c|c|}
\hline $\begin{array}{l}2001 \text { WHO } \\
\text { classification }\end{array}$ & $\begin{array}{l}2008 \text { WHO } \\
\text { classification }\end{array}$ & Comments \\
\hline $\begin{array}{l}\text { Histiocytic } \\
\text { sarcoma }\end{array}$ & Histiocytic sarcoma & No change \\
\hline $\begin{array}{l}\text { Langerhans cell } \\
\text { histiocytosis } \\
\text { Langerhans cell } \\
\text { sarcoma }\end{array}$ & $\begin{array}{l}\text { Tumours derived from } \\
\text { Langerhans cells } \\
\text { (Langerhans cell } \\
\text { histiocytosis, } \\
\text { Langerhans cell } \\
\text { sarcoma) }\end{array}$ & No change \\
\hline $\begin{array}{l}\text { Interdigitating } \\
\text { dendritic cell } \\
\text { sarcoma/tumour }\end{array}$ & $\begin{array}{l}\text { Interdigitating } \\
\text { dendritic cell } \\
\text { sarcoma }\end{array}$ & $\begin{array}{l}\text { Use sarcoma } \\
\text { terminology }\end{array}$ \\
\hline $\begin{array}{l}\text { Follicular } \\
\text { dendritic cell } \\
\text { sarcoma/tumour }\end{array}$ & $\begin{array}{l}\text { Follicular dendritic } \\
\text { cell sarcoma }\end{array}$ & $\begin{array}{l}\text { Use sarcoma } \\
\text { terminology }\end{array}$ \\
\hline \multirow[t]{2}{*}{$\begin{array}{l}\text { Dendritic cell } \\
\text { sarcoma, NOS }\end{array}$} & $\begin{array}{l}\text { Other rare dendritic } \\
\text { cell tumours } \\
\text { including } \\
\text { indeterminate } \\
\text { dendritic cell tumour, } \\
\text { fibroblastic reticular }\end{array}$ & $\begin{array}{l}\text { Addition of } 2 \text { other } \\
\text { tumours of dendritic } \\
\text { origin to recognise } \\
\text { myeloid and stroma- } \\
\text { derived dendritic cells }\end{array}$ \\
\hline & $\begin{array}{l}\text { Disseminated juvenile } \\
\text { xanthogranuloma }\end{array}$ & New entity \\
\hline
\end{tabular}


In the 2008 WHO classification, interdigitating dendritic cell sarcoma/tumours are to be designated interdigitating dendritic cell sarcoma, and follicular dendritic cell sarcoma/ tumours are to be designated follicular dendritic cell sarcomas to better reflect their malignant potential.

In contrast to the 2001 WHO classification, the 2008 WHO classification recognises two additional subtypes of rare dendritic cell tumours. These are encompassed by the term "other rare dendritic cell tumours" and include those that are myeloid-derived dendritic cells such as indeterminate dendritic cell tumour and those that are derived from stroma-derived dendritic cells such as fibroblastic reticular cell tumour. These replace the generic category of dendritic cell sarcoma, not otherwise specified. In addition, those that remain unclassifiable despite extensive workup or show hybrid features should be designated "dendritic cell tumour", not otherwise specified.

What remains unclear is the absence of criteria or terminology to recognise the spectrum of malignant potential for follicular dendritic cell sarcomas and interdigitating dendritic cell sarcomas.
In summary, this group of neoplasms remains a diagnostic and clinical challenge. Due to the lack of phenotypic markers that are unique for most of the subtypes of tumours in this category, extensive panel of immunohistochemical stains in addition to molecular analyses are required. Furthermore, there are no useful stains or molecular studies to distinguish the neoplasms from reactive counterparts.

\section{References}

1. Hume DA, Ross IL, Himes SR et al (2002) The mononuclear phagocyte system revisited. J Leukoc Biol 72:621-627

2. Pileri SA, Grogan TM, Harris NL et al (2003) Tumours of histiocytes and accessory dendritic cells: an immunohistochemical approach to classification from the International Lymphoma Study Group based on 61 cases. Histopathology 41:1-29

3. Swerdlow SH, Campo E, Harris NL, Jaffe ES, Pileri SA, Stein H, Thiele J, Vardiman JW (2008) Pathology and genetics of tumours of hematopoietic and lymphoid tissues. World Health Organization classification of tumours, Chapter 14.353-367. International Agency for Research on Cancer, Lyon 